\title{
The Approach of Egyptian Travel Agencies (Class A) \\ Towards Gaining Environmental Certification
}

\author{
Hala Ahmed Aly Gomaa \\ Tourism Studies Department, Faculty of Tourism and Hotel Management, \\ Helwan University, Egypt
}

\begin{abstract}
Environmental certification is an important step for those travel agencies striving for a unique competitive advantage. The current research attempts to give insights into the perceptions of Egyptian travel agents towards gaining certification. It also investigates and the barriers which hinder the steps taken to communicate and get such certification. A questionnaire has been designed to collect the required data. It has been randomly distributed to a sample of Egyptian travel agencies (Class A). The results reveal that the sample believes in the importance of achieving the environmental certification. Not all of such travel agencies, nevertheless, manage to get eco-certification. One of the many reasons behind such a deficiency is the shortfall in knowledge and adequate information about eco-certification. Recommendations are presented to enhance the abilities of Egyptian travel agencies to get environmental certification.
\end{abstract}

Keywords: Accreditation, Eco-labels, Environmental certification, Travel agencies

\section{Introduction}

Environmental certification is regarded as an instrument exploited to lessen the influences of tourism on the destination, thus the socio-economic and cultural tourism objectives can be achieved. ${ }^{(1)}$ Environmental certification can be explained as "a process by which a logo or seal is awarded to those who meet or exceed a set of criteria that have been set forth by the certification body". (2) Moreover, it can be said that "certification is a process that indicates to interested parties that a tourism provider complies with a specific standard related to the natural environment through an endorsement from the environmental certification scheme".${ }^{(3)}$ In particular, eco-tourism certification is directed to the enterprise dealing with ecotourism context, therefore, high level of criteria with respect to environmental sustainability are considered in this certification. ${ }^{(4)}$ It is noteworthy to conclude that the certification is likely to identify how the business applies the principles of sustainable tourism under specific criteria. ${ }^{(1)}$

In this respect, global events had paid noticeable attention to sustainability and eco-certification in the tourism industry. Eco-certification issue in the tourism industry has come out from the United Nation Earth Summit held in Rio Djanero in 1992 and agreed by 182 countries. This summit indicated that the businesses should meet specific environmental rules for alleviating the impacts on the global environment. ${ }^{(5)}$ Moreover, the Mohonk Agreement held in 2000 involves ecotourism ethics or principles and minimal criteria or measures that should be met to get certified in the sustainable ecotourism. ${ }^{(6)}$ However, the two expressions "environmental certification" and "ecolabel" can be then employed interchangeably. ${ }^{(7)}$

In this regard, different concepts have been raised in eco-certification field. However, it has been announced that the principles of sustainable tourism are therefore referred to as "positive triple bottom line". ${ }^{(8)}$ These triple principles have to be incorporated into the running activities to achieve sustainability. ${ }^{(7)}$ Therefore, tour operators play an effective role in attaining such sustainability by assimilating specific standards and rules into their operations and actions, they can positively affect the conducts of their tourists towards the environment accordingly. ${ }^{(8)}$

It is worth noting that the operation employed for certifying the certification body or the certifier is called accreditation. ${ }^{(9)}$ Hence, the certification program is likely to certify the tourism enterprise whereas the accreditation body is likely to certify the certification program itself. ${ }^{(3)}$ Moreover, the accreditation issue "involves accreditation agencies independent from the certification agency that evaluates a program of study or some institution as meeting certain standards". ${ }^{(3)}$ Furthermore, the accreditation body should certify or accredit the certification body, and this accreditation body "obtains political and financial support intervening as a mediator with governments or NGOs and the industry and can also act as body to arbitrate in matter of conflict". ${ }^{(10)}$ In addition, this accreditation is yielding credibility among the community and customers. ${ }^{(9)}$ It can be said that this acquired certification, in sequence, get regional and international recognition and also motivate the stakeholders to modernize their standards depending upon the progress in the tourism industry. ${ }^{(10)}$

However, it is worth noting that "green market" which is likely to grow, includes those travelers who are encouraged to purchase green tourism services and products. ${ }^{(11)}$ Moreover, about $10 \%-20 \%$ of European travelers 
search for green tourism products, as well as $71 \%$ of the American travelers announce the significance of not harming the environment during tourism experiences. Furthermore, it has been found that $44 \%$ of travelers in U.K. look for information about green policies and strategies pursued by businesses where they hope to buy tourism services and products from. ${ }^{(11)}$ Meanwhile, the expression "Greenwashing" refers to business that announces to adopt sustainable ecotourism practices and activities but it fails to offer them. ${ }^{(12)}$ In addition, gaining eco-label or environmental labeling ${ }^{(13)}$ is a voluntary attitude towards the eco- certification. ${ }^{(14,15)}$ In other words, the certification program is not an obligatory process conducted by a government or an organization to any tourism enterprise. ${ }^{(2)}$ Thus, this voluntary ecocertification plays a great role in providing "a tool for curbing greenwashing and recognizing socially and environmentally responsible companies". ${ }^{16)}$ However, the eco-label is offered as logo or trademark to different types of tourism businesses, such as airlines, tour operators, travel agencies and hotels. ${ }^{(5)}$ Moreover, the members of the initiative or the certification program are therefore given a logo by that certification program. This logo is offered to the business which surpasses the minimum level of the criteria, and can be exhibited in the tourist market to distinguish their tourism products and services. ${ }^{(17)}$ Furthermore, the eco-label therefore "identifies a product that meets a wide range of environmental performance criteria or standards". ${ }^{(15)}$ Most of them are focused in Europe then North and South America. ${ }^{(16)}$ It is worth noting that only $(7 \%)$ of the eco-certification programs are assigned for tour operators, whereas $(68 \%)$ for hotels. ${ }^{(18)}$

It should be added that about (7000) global certified tourism products are related to beaches, tours and accommodation around the world, whereas (6000) of them are existed in Europe. ${ }^{(19)}$ Besides, NGOs and associations working in the tourism industry drive about $2 / 3$ of the programs in the world, and the governmental organizations conduct about twenty programs. In addition, there are more than (100) eco-labels involved in the tourism industry worldwide. $^{(13)}$

Certification programs come into different scales and are run by international, regional and national bodies, which tend to provide sustainable tourism and ecotourism with standards set for tourism businesses to reach sustainability. For examples, in the worldwide scale, the tourism businesses can be certified by Green Globe and Sustainable Tourism Eco-certification program (STEP). ${ }^{(20,8,12)}$ Moreover, the Global Tourism Sustainable Council (GTSC) is a recent organization held in 2010 to handle eco-certification programs for tour operators as well as hotels and destinations. ${ }^{(12)}$ These international certification programs offer tour operators working in sustainability and ecotourism eco-certifications. Certification programs held on the international, regional and national scales have been established by the initiatives of governments, non-governmental organizations and different stakeholders. ${ }^{(21)}$ In this respect, it should be added that "Sustainable Tourism Stewardship Council" (STSC) is considered an international body which puts the global and minimum level of criteria and standards to accredit the certification programs and schemes that can fulfill these standards. ${ }^{(22)}$ However, there is a difference between process-based certification and performancebased certification as the first refers to "a mere demonstration of commitment to observing a standard" whereas the second "confirms that a business actually practices what it claims to do". ${ }^{(1)}$ In this regard, assessing systems are different according to the body which handles the system complying with the required standards or the criteria. Hence, three categories can be distinguished. "The first-party certification/assessment" is handled by the business which evaluates himself and announces its compatibility. "The second-party certification/assessment" is handled by the consumers who evaluate the business and announce its compatibility. Meanwhile "The third-party certification/assessment" is handled by an independent organization with formal criteria which evaluates the business and announces his compatibility. ${ }^{(9)}$ The standards of eco-labels have been accommodated by official bodies such as; World Trade Organization (WTO), International Standards Organization (ISO), and the Global Environmental Labeling Network (GEN) which is classified as a non-profit and a third party organization, as its members have placed criteria to certify tourism services and products with offering technical and informative help in the field. ${ }^{(11)}$ On the other hand, the "funding body" is that one which funds the establishing of the eco-label or eco-certification program. This funding body includes governmental and non-governmental bodies, however, this does not include tourism organizations. ${ }^{(3)}$

On the other hand, the worldwide eco-certification has to be precisely customized to various countries, tourism related-activities and environmental systems, to benefit from a wide range of socio-cultural, legal, economic conditions prevailing in each country with avoiding one global model of eco-certification. ${ }^{(23)}$ However, the criteria of an established global certification can therefore adopt tailored questions to conform to the state prevailing in a specific region or destination. ${ }^{(16)}$ Hence, for enabling the business to select the suitable eco-certification program, the national environmental bodies and national tourist boards can play a role in this process as they should be acquainted with available certification programs in the region. ${ }^{(7)}$ In general, eco-certification schemes are varying according to different features, such as ${ }^{(23)}$ :

1- Geographical location

2- The required tourist sector

3- The environmental context

4- Technical information provided 
5- Auditing and transparency standard

6- Fees and enrolment

7- Equal opportunities of access

8- Tourism product and business type

Meanwhile, some common aspects of the eco-certification programs in the world have been observed such as ${ }^{(16)}$ :

1- They are voluntary attitudes

2- The program offers an awarded logo or a seal for a definite period after obtaining the certification and before the next auditing process is entailed

3- The business is certified after meeting specific criteria or standards offered by the certification programs

4- The offered logos or seals are depended on accomplishing the auditing and assessment process. This process is handled by the first party, the second party or the third party

5- Enrolment fees are given by the certified business to the certification organization. This will enable the laterpartially-to be a self-supporting organization

It is noteworthy to mention that literature clarifies the importance of such eco-certification schemes and ecolabels in sustainable tourism and environmental protection arena. For examples, literature reveals that this certification gives a formal guarantee that the offered services, products and the businesses fulfill specific criteria. In this regard, it can be said that imposing legislations to manage and protect the environment in the tourist sites is not a sufficient method. ${ }^{(21)}$ Thereby, certification is considered an instrument that heartens sustainable practices. ${ }^{(24)}$ Regarding the developing countries, attaining and marketing international eco-labeling schemes are seen as a tool enables tourism businesses to market their offered products to environmentally mature and high spending western tourists. ${ }^{(5)}$ Yet, ecolabeled tourism prevents negative effects of mass tourism on the society and safeguards and improves healthy environmental systems. ${ }^{(25)}$ In this concern, certification programs provide a number of motivations for the tourism business to get certified in the ecotourism and sustainable tourism field regarding marketing and promotional, financial, and technical support. ${ }^{(26)}$ On the other hand, in order to uphold the possessing of eco-certification, tour operators have to carefully select their suppliers who apply sustainable practices in their businesses and have to place them in their marketing materials. ${ }^{(27)}$ It is noteworthy to add that marketing both eco-certification scheme which certifies the business and different tourism enterprises which are certified by the same eco-certification scheme are required from that certified business. ${ }^{(7)}$

However, it is found that studies handling the topic of eco-labels in developing countries are limited. ${ }^{(5,4,28)}$ Moreover, no literature has been found about Egypt investigating the current situations of the travel agencies regarding obtaining eco-labels for their tourism products and eco-tours. Consequently, the present research attempts to gain deep insight into this issue. Hereby, the value of this study is to fill the gap in literature in terms of measuring their approach towards eco-certification and addressing the problems which confront the travel agents in Egypt to get certified.

\section{Research aim}

The aim of the current research is to investigate the approach of the Egyptian travel agencies to gain Eco-certification or Eco-labels in sustainable tourism arena. The research investigates their attitudes towards carrying Eco-certification. Hence, the research objectives are to:

1- Find out the quantity of Egyptian travel agencies carrying Eco-certification or Eco-labels

2- Pinpoint the views of Egyptian travel agencies towards the importance and value of gaining Eco-certification or Eco-labels from their points of views

3- Identify the challenges and hurdles encountering Egyptian travel agencies from gaining eco-certification or eco-labels

4- Propose a frame of recommendations to motivate Egyptian travel agencies achieving eco-certification or ecolabels. Thus sustainability in the tourism industry can be highly guaranteed

\section{Research Methodology}

Given the above objectives, a questionnaire has been designed based on different studies. ${ }^{(23,10,18,7,29,30,20,31,32,24,8,28,12)}$ Questionnaires have been randomly distributed to travel agencies. Only (53) questionnaires were valid representing about (5\%) from the total population of Egyptian travel agencies (Class A). ${ }^{(33)}$ The questionnaires had been distributed from April to November (2013). The travel agency need be situated in great Cairo and interested in organizing environmental tours to be included in the sample selecting criteria. Due to lack of responses, snowballing technique has been adopted this is in order to augment the number of the respondents. 
The questionnaire has been divided into six parts. The first part has been devoted to understand the characteristics of the eco-certification obtained by the sample. The second identified the international certification organizations or certification programs specialized in certifying tour operators working on ecotourism and sustainable tourism field. The third part addressed the perceptions of the sample towards eco-certification. Challenges and obstacles preventing the sample from obtaining such eco-certification are addressed in the fourth part. The benefits that are achieved by a certified Egyptian travel agency due to gaining eco-certification are handled in the fifth part. A number of recommendations of the respondents directed to those in charge and who are working in the tourism industry to facilitate attaining eco-certification are depicted in the last part of the questionnaire. Furthermore, only three parts of the questionnaires have been answered by the respondents (parts: 3, 4 and 6), as well as the first question included in the first part which enquires about whether the respondent gets eco-certification or not. If the respondent has not carried an eco-certification, he is required to answer only the referred questions (3, 4 and 6). Hence, it should be mentioned that three parts of the questionnaire have not been answered by any respondent (parts: 1, 2 and 5) because none of the respondents gets eco-certification or eco-label. These parts are:

1- The majority of the questions placed in first part of the questionnaire. These questions enquire about basic information of the attained eco-certification (but the first question only in this part has been answered)

2- The names of the international certification organizations

3- The initiatives and conducts which support sustainable activities and practices before and after having ecocertification $^{(27,7,20,8,32,15,12)}$

Five-point Likert Scale was used in the questionnaire as, (5): Strongly agree, (1): Strongly disagree. The research has employed a number of statistical techniques such as: Mean, Standard Deviation, Coefficient of Variance, T-Test and Factor analysis. The statistical analysis was implemented by employing SPSS.

\section{Results and Discussions}

Different findings have emerged from the field study.

\section{Theme One: Carrying eco-certification or eco-label in Egypt}

The results have shown that the sample does not join eco-certification schemes. Meaning that (100\%) of the respondents are not involved in any eco-certification program nationally or internationally. In this concern, it can be said that there is a lack of certified business in the sustainable tourism and ecotourism because the certification issue is somehow new and gets limited scale. ${ }^{(26)}$ Therefore, marketing eco-certification to the business providers and clients is required. On the other hand, the sample shows positive attitudes towards the importance of eco-certification, as depicted in the coming theme.

\section{Theme Two: Egyptian travel agents' views towards the importance of eco-certification achievement}

The current theme depicts the perceptions of the Egyptian travel agencies towards obtaining eco-labels or ecocertification. The variables are organized to ask the sample to rate the importance of such certification. Table (1) indicates the results.

Table (1): Egyptian travel agents' views regarding the importance of eco-certification

\begin{tabular}{|c|c|c|c|c|c|c|}
\hline Attributes & Mean & $\begin{array}{c}\text { Std. } \\
\text { Deviation }\end{array}$ & $\mathbf{C V}$ & Rank & $t$-test & $\begin{array}{l}P \text { - } \\
\text { Value }\end{array}$ \\
\hline $\begin{array}{l}\text { 1-To differentiate between real } \\
\text { and unreal green activities } \\
\text { practiced within sustainable } \\
\text { tourism in the marketplace }\end{array}$ & 3.94 & .886 & 22.49 & 3 & 7.751 & $.001 \bullet \bullet$ \\
\hline $\begin{array}{l}\text { 2-To encourage tour operators / } \\
\text { travel agencies enhance the } \\
\text { quality of their performance } \\
\text { towards the environment, } \\
\text { economy, and society }\end{array}$ & 4.15 & .907 & 21.86 & 2 & 9.237 & $.001 \bullet$ \\
\hline $\begin{array}{l}\text { 3-To facilitate finding travel } \\
\text { agency by eco-tourists and other } \\
\text { tourism businesses seeking for } \\
\text { "green" practices }\end{array}$ & 4.17 & .893 & 21.41 & 1 & 9.536 & $.001 \bullet$ \\
\hline $\begin{array}{lrr}4-\text { To } & \text { reinforce } & \text { marketing } \\
\text { activities } & \text { conducted by certified } \\
\text { business/ eco-labeled tour } \\
\text { operator in the marketplace }\end{array}$ & 4.02 & .909 & 22.61 & 4 & 8.159 & $.001 \bullet$ \\
\hline 5-To improve the image of the & 3.94 & .908 & 23.05 & 5 & 7.568 & $.001 \bullet \bullet$ \\
\hline
\end{tabular}


The Approach of Egyptian Travel Agencies (Class A)

\begin{tabular}{|l|c|c|c|c|c|c|}
\hline travel agency as a responsible one & & & & & & \\
\hline $\begin{array}{l}\text { 6-To support brand value and } \\
\text { encourage innovative practices }\end{array}$ & 3.64 & 1.111 & 30.52 & 8 & 4.204 & $.001 \bullet$ \\
\hline $\begin{array}{l}\text { 7-To enhance the operational } \\
\text { systems and managerial actions. }\end{array}$ & 2.53 & 1.449 & 57.27 & 11 & -2.370 & $.022 \bullet$ \\
\hline $\begin{array}{l}\text { 8-To augment the level of tourist } \\
\text { satisfaction of the tourism } \\
\text { experience }\end{array}$ & 3.94 & .929 & 23.58 & 6 & 7.397 & $.001 \bullet$ \\
\hline $\begin{array}{l}\text { 9-To differentiate its tourism } \\
\text { products, services and facilities }\end{array}$ & 3.91 & .946 & 24.19 & 7 & 6.970 & $001 \bullet$ \\
\hline $\begin{array}{l}\text { 10-To represent a competitive } \\
\text { advantage over the rivals in the } \\
\text { marketplace }\end{array}$ & 3.74 & 1.227 & 32.81 & 9 & 4.366 & $.001 \bullet$ \\
\hline $\begin{array}{l}\text { 11-To offer the opportunities to } \\
\text { get financial support for advanced } \\
\text { technology }\end{array}$ & 2.43 & 1.366 & 56.21 & 10 & -3.017 & $.004 \bullet$ \\
$\begin{array}{l}\text { N=53 CV: Coefficient Variance } \\
\text { Likert Scale: 5: Strongly Agree } 4: \text { Agree } 3: \text { Not determined }\end{array}$ & $2:$ Disagree & $1:$ Strongly disagree \\
\hline
\end{tabular}

The results in table (1) show that most of the respondents realize the benefits and advantages of carrying ecocertification for their business setting and sustainable tourism context, as the scores are above the midpoint. They show positive tendency towards most of the attributes standing for the importance of attaining eco-certification. In details, the sample believes that having eco-certificate and eco-label offers an instrument for eco-tourists or other tourism businesses to get "green" practices, as Mean $=4.17, \mathrm{CV}=21.41$. This belief coincides with the view explained by literature. $^{(8)}$

However, the respondents recognize that eco-certification encourages businesses to enhance the quality of their performance towards the economy, environment and society as Mean $=4.15, \mathrm{CV}=21.86$. Moreover, the opinions of the sample announce also that the eco-certification differentiates between real and unreal green activities practiced within sustainable tourism in the marketplace (Mean $=3.94, \mathrm{CV}=22.49$ ). It is noteworthy to add that these later two points have been conformed to the notion of literature. ${ }^{(7)}$ In this respect, it can be said that this certification is likely to be distinguished by distribution channels and eco-tourists and is considered as an added value for the businesses. ${ }^{(18)}$ In addition, in order to reveal the effect of eco-labeled products on the eco-tourists' conducts, ${ }^{(34)}$ it is asserted that these conducts towards tourism products eco-labeled by Green Globe in New Zealand are actually positive. ${ }^{(34)}$

Yet, the results generated from the table demonstrate that getting eco-certification reinforces marketing activities conducted by certified business/eco-labeled tour operator in the marketplace (Mean $=4.02, \mathrm{CV}=22.61$ ). It should be mentioned that this view is matched with the approach referred by researchers. ${ }^{(23,18)}$ The sample reveals also that eco-certification is likely to improve the tour operator's image in the tourism market as a responsible one (Mean $=$ $3.94, \mathrm{CV}=23.05)$. This idea is agreed with what has been highlighted by literature. ${ }^{(20)}$ It can be added that this certification will maintain its relationships with their employees, product suppliers, and host communities who tend to uphold this tour operator for their attitudes towards sustainability. ${ }^{(20)}$

The respondents declare that this eco-certification augments the level of tourist satisfaction of the tourism experience $(\mathrm{Mean}=3.94, \mathrm{CV}=23.58)$ as asserted by literature. ${ }^{(28)}$

The respondents illuminate that this eco-certification differentiates their tourism products, services and facilities (Mean= 3.91, CV=24.19). More, they realize its importance regarding supporting their brand value and encouraging innovative practices $(\mathrm{Mean}=3.64, \mathrm{CV}=30.52$ ). These two later views have been supported by the insights of scholars. ${ }^{(32)}$ They also think that this eco-certification represents a competitive advantage for the business carrying it over the rivals in the marketplace (Mean $=3.74, \mathrm{CV}=32.81$ ). This is agreed with the ideas of researchers. ${ }^{(24)}$ In this concern, the results generated from $t$-test emphasize the significance of these results as the above mentioned section highlights.

On the other hand, the sample has not perceived few attributes as benefits or advantages gained from ecocertification. The sample has not shown positive tendency towards the attribute of "offering opportunities for sustainable operator to get financial and technical support from the certification body to acquire advanced technology" (Mean=2.43, CV=56.21), whereas some scholars ${ }^{(31)}$ emphasize the importance of this point to the eco-certified business. In addition, they show the same trend towards the attribute of "enhancing the operational systems and managerial actions as a result of having eco-certification" (Mean=2.53, $\mathrm{CV}=57.27$ ) despite the researchers believe that this consideration is an opportunity for sustainable businesses. ${ }^{(32)}$ 


\section{Theme Three: Challenges hinder eco-certification attaining}

A range of challenges have been revealed by the sample in achieving eco-certification. Table (2) shows these findings.

Table (2): Obstacles facing Egyptian travel agents to attain eco-certification

\begin{tabular}{|c|c|c|c|c|c|c|}
\hline Obstacles & Mean & $\begin{array}{c}\text { Std. } \\
\text { Deviation }\end{array}$ & $\mathrm{CV}$ & Rank & $\mathbf{T}$ & $p$-value \\
\hline $\begin{array}{l}\text { 1-Difficulties in certification process } \\
\text { because of language barrier }\end{array}$ & 2.70 & 1.462 & 54.15 & 6 & -1.503 & .139 \\
\hline $\begin{array}{l}\text { 2- Much information and data needed for } \\
\text { certification are hard to be documented }\end{array}$ & 4.02 & 1.009 & 25.10 & 1 & 7.348 & $.001 \bullet \bullet$ \\
\hline 3- Shortage in well-trained staff & 3.58 & 1.064 & 29.72 & 4 & 4.002 & $.001 \bullet \bullet$ \\
\hline $\begin{array}{l}\text { 4- Lack of know-how and experts needed } \\
\text { to apply the requirements claimed by } \\
\text { certification or eco-labels schemes }\end{array}$ & 3.72 & 1.099 & 29.54 & 3 & 4.751 & $.001 \bullet \bullet$ \\
\hline $\begin{array}{l}\text { 5- Lack of financial resources for getting } \\
\text { eco-certification }\end{array}$ & 2.43 & 1.394 & 57.37 & 7 & -2.957 & .005 \\
\hline $\begin{array}{l}\text { 6- shortfall in knowledge about the } \\
\text { method or the stages to do so / Shortage in } \\
\text { sufficient information about } \\
\text { environmental certification or eco-labels }\end{array}$ & 4.19 & 1.110 & 26.49 & 2 & 7.793 & $.001 \bullet \bullet$ \\
\hline $\begin{array}{l}7-\text { we do not find importance or } \\
\text { advantages from attaining eco-certification } \\
\text { or eco-labels for our business }\end{array}$ & 2.89 & 1.103 & 38.17 & 5 & -.747 & .459 \\
\hline
\end{tabular}

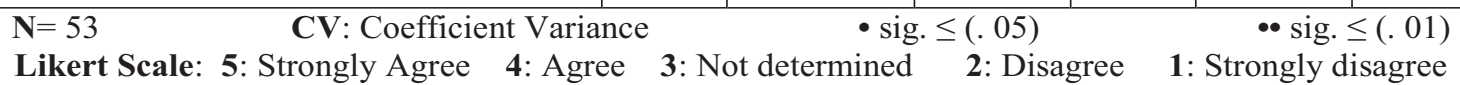

The results in table (2) indicate the different obstacles and barriers deterring the endeavors for attaining ecocertification. Much information and data needed for certification are hard to be documented $(\mathrm{Mean}=4.02, \mathrm{CV}=25.10)$. This difficulty which is announced by the respondents as a barrier for eco-certification achievement, especially for small and medium businesses, is matched with the idea indicated by some scholars. ${ }^{(29)}$

Yet, shortfall in knowledge about the method or the procedures to get certified or shortage in sufficient information about environmental certification or eco-labels is announced by the sample as a barrier encountering attaining eco-certification (Mean $=4.19, \mathrm{CV}=26.49$ ). Different studies emphasize the shortage of this type of information. ${ }^{(7,29,30)}$ It is also supported by literature which announces that: "most sustainable tourism certification programs are nationally based, operate only regionally, and have limited consumer recognition". ${ }^{(12)}$

Besides, lack of know-how and experts needed to apply the requirements and standard claimed by certification or eco-labels schemes is another barrier declared by the respondents (Mean=3.72, CV=29.54). In addition, shortage in well-trained staff is considered a further barrier (Mean=3.58, CV=29.72). It is worth noting that these referred barriers are indicated by some researchers. ${ }^{(10,18)}$

On the other hand, the sample has announced that they do not find importance or advantages from attaining eco-certification or eco-labels for their businesses (Mean $=2.89, \mathrm{CV}=38.17)$. This view has been declared by literature as a result emerged from a field research. ${ }^{(30)}$

On the other hand, the sample has not considered foreign language and financial resources as barriers for certification attainment. In details, the sample has not mentioned that foreign language is a difficulty or a trouble facing them during the certification process (Mean $=2.70, \mathrm{CV}=54.15)$ although literature has reported this attribute as a barrier deterring eco-certification steps especially for small and medium businesses. ${ }^{(29)}$

Yet, the respondents indicate that lack of financial resources required to get eco-certification is not a challenge for them $(\mathrm{Mean}=2.43, \mathrm{CV}=57.37)$. Despite their view, literature has a different one. For examples, some studies announce that lack of financial resources required to get certified is considered a challenge confronting small businesses. ${ }^{(10,18)}$ In addition, literature supports the same opinion, as it explains that the expenses needed for accomplishing accreditation and certification process represent actually a great obstacle to obtain certification regarding its application, operating 
The Approach of Egyptian Travel Agencies (Class A)

and implementing the required criteria. ${ }^{(19)}$ Finally, it is worth noting that $t$-test results are significant for many barriers, as $p$-value $>.01$, which emphasizes that the respondents suffer from the above mentioned obstacles. Accordingly, the government has to offer assistance to these businesses to help them overcome these obstacles. ${ }^{(10)}$ The coming theme clarifies this later perception.

\section{Theme Four: The need for governmental support}

The sample has declared that the role of Egyptian authorities has to be activated through a range of different incentives and motivations. The respondents identify their suggestions regarding the methods that can assist them to get certified in the ecotourism and sustainable tourism context. These suggestions are to:

1- Conduct specialized training courses for acquainting travel agencies with eco-certification bodies worldwide, its importance, process and steps needed to accomplish the requirements of the certification, as the majority of the respondents reveal

2- Give more consideration on qualifying tour operators, eco-guides, tourism operators in tourist attractions through training courses to raise their environmental awareness according to their positions, as a significant number of the sample declare

3- Offer technical assistance to Egyptian travel agencies regarding ongoing consultancy, full required information about the eco-certification issues, and full list of specialized tour operators abroad working in ecotourism field

4- Subsidize the travel agencies to afford the certification costs

5- Offer incentives for travel agencies to encourage them gaining eco-certification

However, different stakeholders such as current and potential visitors and host community are likely to reinforce sustainable tourism development. ${ }^{(35)}$ Moreover, literature mentions that the government which is considered as one of the stakeholders should support most of the eco-certification programs to facilitate its emerging and continuation, as well as to present the destination worldwide acceptance in the tourism marketplace. ${ }^{(4)}$ In details, the government can play a significant role in supporting eco-certification and accreditation holding through; adapting the environment, displaying the best practices and experiences, identifying the standard, offering motivations such as donations or loans. ${ }^{(19)}$ It can be added that the government in Costa Rica for example has financed the first request of the application of the certification. Besides, the government can play a role in raising the awareness of the host community, offering them training courses, and practicing leadership and controlling process. ${ }^{(4)}$ Consequently, if the governmental tourism authorities in Egypt announce they are ready to support them financially, it is thought that this approach will motivate travel agencies to think about achieving eco-certification. In addition, in order to demonstrate the role of government in motivating the business to be certified, it can be mentioned that governmental authorities are likely to give advantages and benefits to the certified business by an accredited program. ${ }^{(26)}$ As the government and NGOs are likely to announce a range of "purchasing policies" enhancing the consumption of products that meet exact criteria. ${ }^{(26)}$

\section{Factor analysis}

Table (3) elucidates the main issues generated by factor analysis in terms of the main challenges of eco-certification achievement as declared by the respondents. The Bartlett's Test of Sphericity was significant at $P=.001\left(\mathrm{x}^{2}=114.517\right)$. The Kaiser-Meyer-Olkin measure of sampling adequacy is .568. Therefore, the data is suitable for employing factor analysis. Eigenvalues greater than one were extracted. However, two main factors are identified. Factor (1): Insufficient technical experiences (explains $31.577 \%$ of the total variance). Factor (2): unavailable financial and information resources (explains $27.465 \%$ ).

Table (3): Factor analysis of the main challenges of eco-certification achievement

\begin{tabular}{|c|c|c|c|c|}
\hline The Obstacles & $\begin{array}{c}\text { Factor } \\
\text { loading }\end{array}$ & Eigenvalue & $\begin{array}{c}\text { Variance } \\
\text { explained } \\
(\mathbf{\%})\end{array}$ & $\begin{array}{c}\text { Cumulative of } \\
\text { variance (\%) }\end{array}$ \\
\hline $\begin{array}{c}\text { Factor (1): Insufficient technical } \\
\text { experiences }\end{array}$ & & 2.210 & 31.577 & 31.577 \\
\hline $\begin{array}{c}\text { Lack of know-how and experts needed } \\
\text { to apply the requirements claimed by } \\
\text { certification or eco-labels schemes }\end{array}$ & .919 & & & \\
\hline $\begin{array}{c}\text { Shortage in well-trained staff } \\
\text { because of language barrier } \\
\text { beculties in certification process }\end{array}$ & -.911 & & & \\
\hline $\begin{array}{c}\text { We do not find importance or } \\
\text { advantages from attaining eco- } \\
\text { certification or eco-labels for our } \\
\text { business }\end{array}$ & -.317 & & & \\
\hline Factor (2): unavailable financial and & & 1.923 & 27.465 & \\
\hline
\end{tabular}




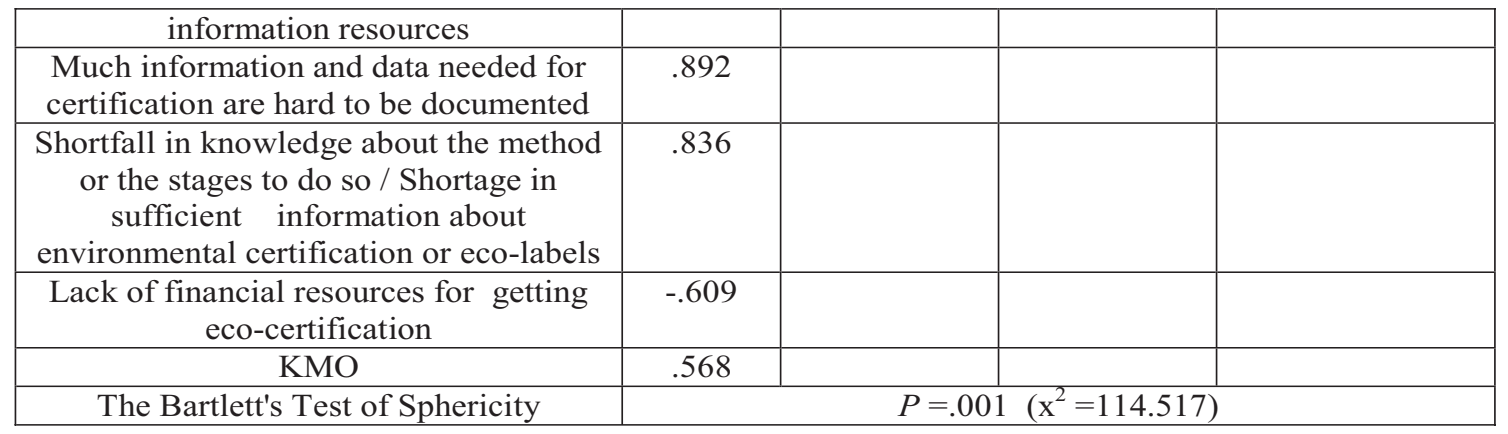

In addition, table (4) elucidates the main issues generated by factor analysis regarding the key points of the importance of eco-certification as determined by the sample. The Bartlett's Test of Sphericity was significant at $P=.001\left(\mathrm{x}^{2}\right.$ =293.983). The Kaiser-Meyer-Olkin measure of sampling adequacy is .752. Therefore, the data is suitable for employing factor analysis. Eigenvalues greater than one were extracted. However, three main factors are emerged. Factor (1): Effective marketing, managerial and financial support (explains $33.982 \%$ of the total variance). Factor (2): Differentiating tool towards green environmental performance (explains 19.719\%). Factor (3): acquisition of ecotourists, suppliers, brand name and customer satisfaction (explains $16.443 \%$ of the total variance).

Table (4): Factor analysis of the key points of the eco-certification importance

\begin{tabular}{|c|c|c|c|c|}
\hline The importance & $\begin{array}{l}\text { Factor } \\
\text { loading }\end{array}$ & Eigenvalue & $\begin{array}{l}\text { Variance } \\
\text { explained } \\
(\%)\end{array}$ & $\begin{array}{l}\text { Cumulative of } \\
\text { variance }(\%)\end{array}$ \\
\hline $\begin{array}{l}\text { Factor (1): Effective marketing, } \\
\text { managerial and financial support }\end{array}$ & & 3.738 & 33.982 & 33.982 \\
\hline $\begin{array}{l}\text { To improve the image of the travel } \\
\text { agency as a responsible one }\end{array}$ & .860 & & & \\
\hline $\begin{array}{l}\text { To represent a competitive advantage } \\
\text { over the rivals in the marketplace }\end{array}$ & .794 & & & \\
\hline $\begin{array}{l}\text { To enhance the operational systems and } \\
\text { managerial actions. }\end{array}$ & .794 & & & \\
\hline $\begin{array}{l}\text { To offer the opportunities to get } \\
\text { financial support for advanced } \\
\text { technology }\end{array}$ & .731 & & & \\
\hline $\begin{array}{l}\text { To reinforce marketing activities } \\
\text { conducted by certified business/ eco- } \\
\text { labeled tour operator in the marketplace }\end{array}$ & .705 & & & \\
\hline $\begin{array}{l}\text { Factor (2): Differentiating tool towards } \\
\text { green environmental performance }\end{array}$ & & 2.169 & 19.719 & 53.702 \\
\hline $\begin{array}{l}\text { To encourage tour operators / travel } \\
\text { agencies enhance the quality of their } \\
\text { performance towards the environment, } \\
\text { economy, and society. }\end{array}$ & .922 & & & \\
\hline $\begin{array}{l}\text { To differentiate between real and unreal } \\
\text { green activities practiced within } \\
\text { sustainable tourism in the marketplace }\end{array}$ & .783 & & & \\
\hline $\begin{array}{l}\text { To differentiate its tourism products, } \\
\text { services and facilities }\end{array}$ & .627 & & & \\
\hline $\begin{array}{l}\text { Factor (3): acquisition of eco-tourists, } \\
\text { suppliers, brand name and customer } \\
\text { satisfaction }\end{array}$ & & 1.809 & 16.443 & 70.145 \\
\hline $\begin{array}{l}\text { To facilitate finding travel agency by } \\
\text { eco-tourists and other tourism } \\
\text { businesses seeking for "green" practices }\end{array}$ & .862 & & & \\
\hline $\begin{array}{l}\text { To augment the level of tourist } \\
\text { satisfaction of the tourism experience }\end{array}$ & .745 & & & \\
\hline $\begin{array}{l}\text { To support brand value and encourage } \\
\text { innovative practices }\end{array}$ & .584 & & & \\
\hline KMO & .752 & & & \\
\hline The Bartlett's Test of Sphericity & \multicolumn{4}{|c|}{$P=.001 \quad\left(\mathrm{x}^{2}=293.983\right)$} \\
\hline
\end{tabular}




\section{Conclusion}

The current research has been conducted to reveal the approach of the Egyptian travel agencies (Class A) towards carrying eco-labels or eco-certification and analyze the reasons standing behind that approach. However, it can be said that there are not any positive steps taken by the respondents in the past or at present in order to carry such certification. Yet, their responses indicate their desires to understand the details of eco-certification in terms of how to join, what to do, and who will financially support their initiatives. This means they are ready to get eco-certified in the future if some barriers have been destroyed and if they get financed by the government or the public sector in the tourism industry. In particular, the research reveals that the sample is not involved in any certification programs for eco-certification on a national or international level. This is due to the fact that there are numerous challenges deterring their initiations to reach eco-certification. For example, information and data needed for certification are hard to be documented and there is lack of information about environmental certification and eco-labels. This is in addition to shortage in well-trained staff which was derived from the lack of know-how and experts needed to apply the requirements of eco-certification. Accordingly, the respondents suggest that the tourism public sector and the governmental authorities that are involved in the sustainable tourism and ecotourism in Egypt have to show financial and technical support to encourage them contacting certification programs. On the other hand, the respondents believe in the value of gaining eco-certification in the ecotourism and sustainable tourism field regarding; offering an instrument for eco-tourists or other tourism businesses this is in order to get "green" practices, encouraging the businesses to enhance the quality of their performance towards the economy, environment and society, differentiating between real and unreal green practiced activities, reinforcing marketing activities conducted by certified business, improving the tour operator's image in the tourism market as a responsible one, augmenting the level of tourist satisfaction of the tourism experience, and differentiating their tourism products, services and facilities, for examples. The coming part exhibits the recommendations of the research.

\section{Recommendations}

The sample has announced a number of visions and suggestions to start taking actions towards getting eco-certification for their activities. Accordingly, a number of recommendations have been suggested in order to support the visions of the sample travel agencies and assist them to maintain sustainable practices in tourism industry of Egypt. Communicating and working with global occasions (the summits) caring about environmental and sustainable tourism issues are highly recommended. In this regard, the global bodies can be communicated as a further step to assist in announcing an eco-certification program in Egypt. This program is going to award Egyptian tourism enterprises especially tour operators or travel agents who offer tours in the field of ecotourism and sustainable tourism. The program should clearly announce the criteria and the offered incentives to the certified businesses. It is thought that The Egyptian Environmental Affairs Agency (EEAA) and the Ministry of Tourism need to be represented in the proposed body which will offer the program. The Egyptian Travel Agents Association has to play a vital role as a communication channel between that body and the tourism businesses in Egypt. However, the following steps are suggested to be initiated by by the Ministry of Tourism and the Egyptian Travel Agents Association:

1- Building complete and precise database of the available international certification organizations, with clear and full required criteria announced by every organization. It is thought that this step is likely to enrich the knowledge of the applicants about the global requirements

2- Playing proactive and positive roles in consulting and connecting the travel agency which needs to be certified with the suitable certification organization in the world.

4- Conducting comprehensive training courses to inform the travel agents about the requirements of ecocertification announced by global certification bodies.

5- Offering technical and financial assistance for the travel agents.

\section{Further Research}

Further research can investigate the role of public sector in Egypt in supporting travel agencies towards gaining ecocertification.

\section{Limitations}

The current study concentrates only on studying the approach or attitudes of the Egyptian tour operator or travel agency dealing with the environmental tours towards gaining eco-certification and eco-labels, not on the overall environmental management systems applied on other activities and functions of the travel agency. On the other hand, it should be noted that the detailed criteria of the international certification organizations required to get certified or eco-labeled are not the core of the current research.

\section{References}

1-Muriithi, J. (2013): "Eco-certification and Insertion of Socioeconomic and Cultural Best Practices in Ecotourism Operations in Kenya", International Journal of Humanities and social Science, Vol.3, No.5, PP: (216:224). 
2-Poser, E. (2009): "Setting Standards for Sustainable Tourism: An Analysis of US Tourism Certification Programs", Master Thesis, Nicholas school of the Environment, Duke University, PP: (7).

3-Darling, J. (2010): "Dunedin Tourism Operators Perceptions of Environmental Certification Schemes in New Zealand", Master Thesis, University of Dunedin, New Zealand, PP: (40,41).

4-Pina, R. (2004): "Ecolabelling, Certification and Accreditation: Elements of a Possible Model for the Ecotourism Industry in Southern and Eastern Africa", M.phil report, The University of Stellenbosch, PP: $(9,11,24,25)$.

5-Sasidharan,V; Sirakaya, E. and Kerstetter, D. (2002): "Developing Countries and Tourism Ecolabels", Tourism Management,Vol.23, Issue 2, PP: (161:174), Elsevier Science Ltd.

6-Pappin, F. and Esakin, T. (2013): "Virtual Sustainability Case Study: Very Sustainable Eco Tours (VEST)", Ryerson University, PP: $(9,22)$.

7-Bien, A. (2006): "A Simple User's Guide to Certification For Sustainable Tourism and Ecotourism", The Center for Ecotourism and Sustainable Development, The International Ecotourism Society and Rainforest Alliance, $3^{\text {rd }}$ Ed., PP: $(4,7,10,21,22)$.

8-Sustainable Travel International (2010):"NTA Tour Operators Guide to Sustainable Tourism", Sustainable Travel International, Washington, U.S.A, PP: $(7,8,19,20)$.

9-Cox, L; Saucier, M; Cusick, J; Richins, H. and McClure, B. (2008): "Achieving Sustainable Tourism in Hawai'i Using a Sustainability Evaluation System", College of Tropical Agriculture and Human resources: University of Hawai'i at Manoa, Hawai'i, PP: (1:6).

10-Eaglen, A. and Font, X. (2002): "Ecotourism Certification and Accreditation: Some Effects on the Private Sector", Leeds Metropolitan University (UK), Centre deBiodiversitat,http://fama2.us.es:8080/turismo/turismonet1/economia\%20del\%20turismo/turismo\%20y\%20medi o\%20ambiente/ecotourism\%20certification\%20and\%20acreditation.pdf, Accessed 15-11-2012, at: 12:02.

11-Piper, L. and Yeo, M. (2011): "Ecolabels, Eco-certification and Ecotourism", Sustainable Tourism: Socio-Cultural, Environmental and Economic Impact, PP:(279-294).

12-Mcgahey, S. (2012): "The Ethics, Obligations, And Stakeholders of Ecotourism Marketing", Mykoko Romerio Universitetas-Universytet Wroclawski, Vol.6, No.14, PP: (75-88).

13-Anderson, L; Mastrangelo, C; Chase, L; Kestenbaum, D. and Kolodinsky, J. (2012): "Eco-labeling Motorcoach Operators in the North American Travel Tour Industry: Analyzing the Role of Tour Operator", Journal of Sustainable Tourism, 1-15, Routledge.

14-Ryglova, K. (2007): "Eco-certification as a Tool of Sustainable Tourism", AGRIC.ECON-CZECH, Vol.53, No.3, Czech Republic, PP: (138:143).

15-Golden, J. S. (2010): "An Overview of Eco labels and Sustainability Certifications in the Global Marketplace", Corporate Sustainability Initiative: Nicholas Institute for Environmental Policy Solutions: Duke University, PP: $(14: 20)$.

16-Honey, H. (2008):"Setting Standards: Certification Programmes for Ecotourism and Sustainable Tourism", In: A. Stronza and W.H. Durham (Eds.), Ecotourism And Conservation In The Americas, CAB International, U.K., PP: $(235,242,245,255)$.

17-Synergy, (2000): "Tourism Certification: An Analysis of Green Globe 21 and Other Tourism Certification Programmes", A report by Synergy for WWF,U.K., PP: $(9,14)$.

18-Font, X. (2003): "Labelling and Certification: Benefits and Challenges For Sustainable Tourism Management and Marketing", ECOCLUB.com:E-Paper Series,Nr.9, PP:(1:4).

19-......... (2013): "Critical Review of Certification and Accreditation in Sustainable Tourism Governance", PP:(1:11).

20-Conservation International; Rainforest Alliance; The United Nations Environment Programme; Adventure Travel Trade Association And Global Environment Facility (2007): "Integrating Good Practices Into A Tour Operator's Supply Chain: A Business to Business Tool Kit", PP: (7,21,30).In: www.conservation.org.ec/.../imagenes/B2B\%20Tool. Accessed 31-1-2013, at: 11:07 pm.

21-Font, X; Sanabria, R. and Skinner, E. (2003): "Sustainable Tourism and Ecotourism Certification: Raising Standards and Benefits", Journal of Ecotourism, Vol.2, No.3, PP: (213:218).

22-Klintman, M. (2012): "Issues of Scale in the Global Accreditation of Sustainable Tourism Schemes: Toward Harmonized Re-embeddedness?", Sustainability: Science, Practice \& Policy, Volume 8, Issue 1, PP: (59:69). 
23-Buckley, R. (2002): "Tourism Ecolabels", In: www.estig.ipbeja.pt/ ac_direito/19335-1.pdf., Accessed 6-5-2013, at: $17: 45 \mathrm{pm}$.

24-Presbury, R. and Edwards, D. (2010): "Sustainable Operations Management", Goodfellow Publishers Limited, Woodeaton, Oxford, U.K., P:(18).

25-Vail, D. (2004): "An Ecotourism Quality Label For Maine? Insights From Sweden's "Nature's Best" Initiative", Maine Policy Review, Vol. 13, Issue 2, PP:(76:87).

26-Rome, A. (2005): "Current Range of Incentives Offered To Business By 'Green' Certification Programs And Quality-Ratings Systems", A publication of Center on Ecotourism and Sustainable Development: The International Ecotourism Society, PP: (4:6).

27-Font, X. and Carey, B. (2005): "Marketing Sustainable Tourism Products", United Nations Environment Programme and Regione Toscana, Italy, PP: $(15,16)$.

28-UNEP; United Nations Foundation and the Southern African Trust (2010): "Accrediting Sustainable Tourism Certification-Africa", meeting report: Consultative Workshop on Accreditation of Sustainable Tourism Certification to Support the Establishment of the Tourism Sustainability Council (TSC), 18-20 Jan., South Africa, $\mathrm{P}:(17)$.

29-Bien, A. and Russillo, A. (2006): "International Accreditation System and Consolidation of National Systems for Sustainable Tourism Certification to Facilitate Small and Medium Enterprises'(SMEs) Competitiveness and Market Access : Strategies for engaging small entrepreneurial, indigenous-run, and community-based tourist enterprises in best practices and certification of sustainability", Center on Ecotourism and Sustainable Development: The international ecotourism society, PP:(44,45).

30-Carmody, J. and Zeppel, H. (2006): "Environmental Practices of Tourism Operators In The Daintree Rainforest, North Queensland, Australia", Proceeding of New Zeland Tourism \& Hospitality Research Conference 2006, New Zeland Tourism \& Hospitality Research Conference, New Zeland: 5-7 December, 2006, Dunedin, New Zeland, PP:(1:16).

31-Bustam, T. and Stein T. (2010): "Integrating Sustainability Into Your Ecotourism Operation", University of Florida: IFAS Extension, U.S.A., PP: (1:5).

32-Ngesa, F. and Cavagnaro, E. (2010): "Sustainable Tour Operating Practices: Setting up a Case Study of Inbound Tour Operators in Kenya", Paper presented at EuroCHRIE conference, 25-27 October 2010, Amsterdam.

33-Ministry of Tourism (2013): http://www.tourism.gov.eg, Accessed 15-4-2013, at: 20:30 p.m.

34-Reiser, A. and Simmons, D. (2005): "A Quasi-experimental Method for Testing the Effectiveness of Ecolabel Promotion", Journal of Sustainable Tourism, Vol.13, Issue 6, PP:(590-616).

35-Jadhav, U; Mahapatra, A. and Sharma, P. (2013): "Role of Tour Operators in Sustainable Tourism Development in Bhutan", International Journal of Business Intelligent (IJBI), Vol. 2, Indo-Bhutan International Conference On Gross National Happiness, PP: (159:165).

\section{اتجاه شركات السياحة المصرية ( فئة أ ) نحو الحصول على الثهادة البيئية}

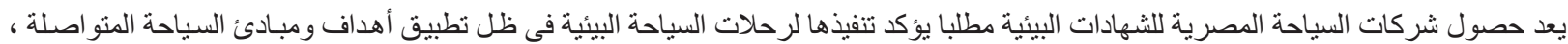

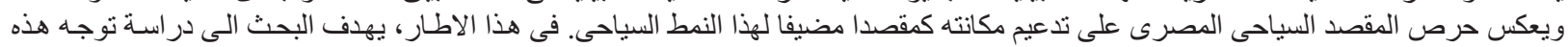

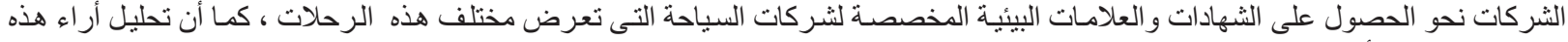

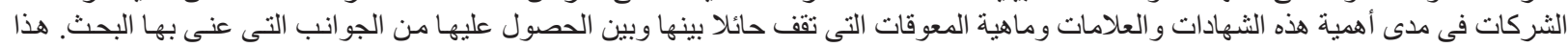

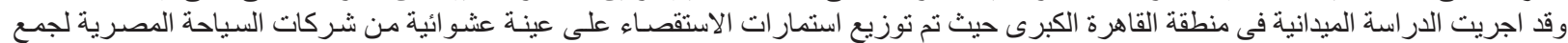

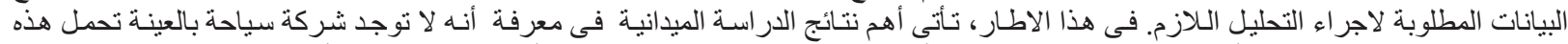

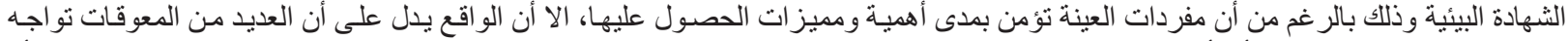

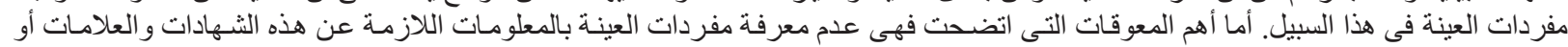

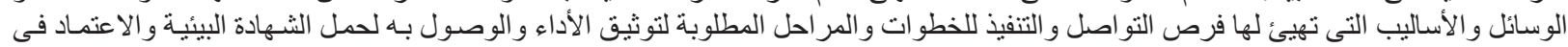

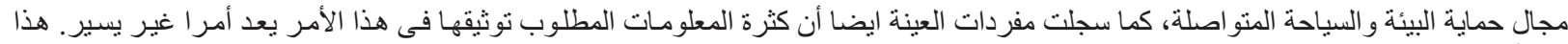

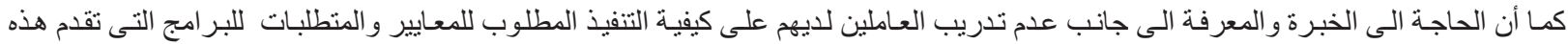

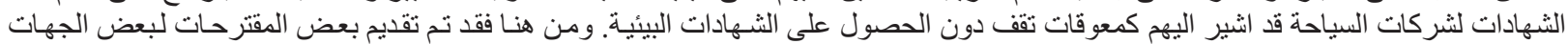

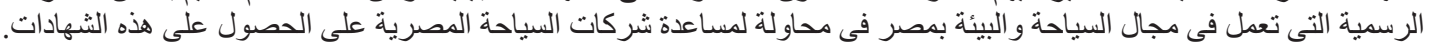

